\title{
MORBIDITY TRENDS OF UNINTENTIONAL POISONINGS IN CHILDREN AND YOUNG PEOPLE IN KLAIPEDA COUNTY (LITHUANIA)
}

\author{
Birutė Strukčinskienè ${ }^{1}$, Sigitas Griškonis ${ }^{1,2}$ \\ ${ }^{1}$ Klaipeda University, ${ }^{2}$ Klaipeda University Hospital, Lithuania
}

Key words: poisonings, children, young people, trends, morbidity.

\begin{abstract}
Summary
Unintentional poisonings in children, teenagers, and young people result in significant mortality and morbidity globally. The aim of the study was to estimate morbidity trends due to unintentional poisonings in children and young people with focus on unintentional poisonings from medicines, alcohol, and illicit drugs in Klaipeda County (Lithuania).

The data (over 2003-2015) were obtained from the Health Insurance Fund and the Department of Statistics in Klaipeda. The longitudinal study was performed, and regression analysis was applied for the study. The children aged 0 to 14 and teenagers aged 15 to 19 treated at the hospital because of serious poisonings were examined. The morbidity per 1000 children was calculated.

Among patients treated in the Klaipeda County hospitals because of serious poisonings, $48 \%$ were children aged 0 to 19 years. In children aged 0 to 14 years, treated at the hospitals as inpatients, $48 \%$ were treated because of the poisonings from medicines, $29 \%$ - from alcohol, $1 \%$ - from illicit drugs, and 22\% - from other substances. In the young people aged 15 to 19 years, the main substance of serious poisonings was alcohol $-52 \%$, on the second place of hospital-treated poisonings were unintentional poisonings from medicines (34\%), and poisonings due to illegal drugs were very few (5\%). The study showed that the main substances of poisoning for children aged 0 to 14 years were medicines, whereas for ones aged 15 to 19 years were alcohol. The study revealed declining trends of non-fatal poisonings due to medicines in both children and teenagers groups, and male and female subgroups. However, there were no significant
\end{abstract}

changes of poisonings due to alcohol in young people aged 15 to 19 years, and in girls aged 0 to 14 years. Poisonings due to drugs were very rare, and showed no significant change. Parents and children education and information within child safety prevention projects/programs could influence the decrease in poisonings due to medicines. However, more attention should be put on prevention of alcohol use among children and teenagers, with focus on legislation and enforcement.

\section{Introduction}

Unintentional poisonings in children and young people result in significant mortality and morbidity globally $[1,2$, 3]. In the WHO (World Health Organization) European Region, injuries are a leading cause of death in young people aged 5-49 years; injuries cause half of all deaths in young people aged 15-29 years, third in children of 5-14 years, and a quarter in adults of 30-49 years [2]. According to European Association of Injury Prevention and Safety Promotion (EuroSafe), annually in Europe about 30 million people are injured at home and during leisure time activities [3]. The EU average rate of home and leisure injuries is 38.93 per 1000 population [4]. Unintentional poisonings are among major cause of injuries in Europe. Despite the fact that deaths due to poisonings showed $58.4 \%$ decreasing change in WHO European Region over 2000-2015 (from 21, 909 to 9, 124) [2], enough attention should be put to children and young people poisonings, their causes, trends, and possibilities for prevention.

According to the National Center for Health Statistics (NCHS) in the US, poisoning is the leading cause of injury death in the United States, where drugs - both pharmaceutical and illicit - cause the vast majority of poisoning deaths. Since 1999, the age-adjusted drug-poisoning death rate has more than tripled, from 6.1 per 100,000 in 1999 to 16.3 per 100,000 in 2015 [5]. According to CDC (Centers for 
Disease Control and Prevention) in the US, every day, over 300 children in the United States ages 0 to 19 are treated in an emergency department, and two children die, because of being poisoned [6]. Paediatric poisonings are a significant percentage of admissions to the paediatric intensive care unit in the US [7].

Ingested poisoning is still an issue in children and young people aged 0 to 19 years in New Zealand. There most of children poisonings $(86 \%)$ occur in children aged 0 to 5 years, and with these being further concentrated in children aged one to two years (57\%)[8].

Profile of acute poisonings varies from country to country depending on accessibility of substances and socio-economic status of people [9]. Medications and domestic chemicals in various countries and continents often poisoned young children, whilst teenagers were most often poisoned with alcohol [6 -12].

In Lithuania, $15 \%$ of injury deaths were fatal poisonings in 2015. Mortality from unintentional poisonings was 16.59 per 100, 000 population, while mortality from road traffic injuries was 10.57 per 100,000 population in the country [13]. Studies on trends of morbidity and mortality due to unintentional poisonings help to identify the main cause and substances of poisonings, and to plan measures for poisoning prevention and safety promotion at national, local, and community levels.

The aim of the study was to estimate morbidity trends due to unintentional poisonings in children and young people with focus on unintentional poisonings from medicines, alcohol, and illicit drugs in Klaipeda County (Lithuania).

\section{Materials and Methods}

Data on children and teenagers treated at the hospitals from serious poisonings were analysed. Information from Klaipeda County hospitals (Lithuania) were used for the

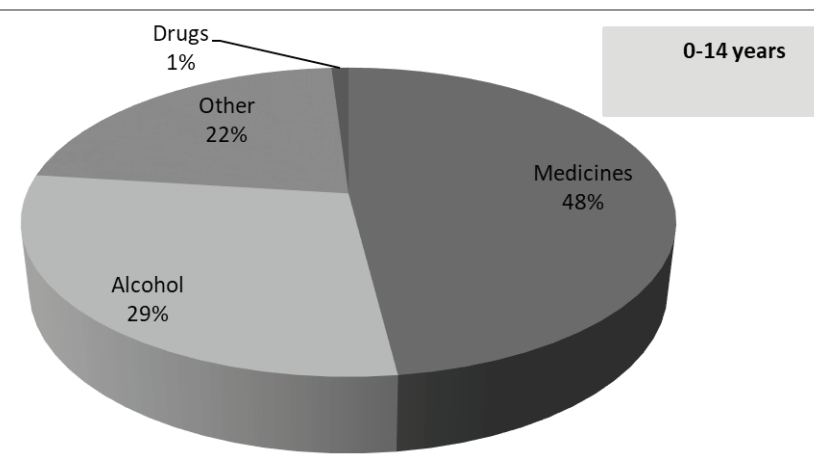

Figure 1. Unintentional poisonings in children aged 0-14 years (inpatients) study. Longitudinal study on morbidity from unintentional poisonings was performed. The data (over 2003-2015) were obtained from the Health Insurance Fund and the Department of Statistics in Klaipeda. The morbidity per 1000 children was calculated. Children aged 0 to 14 and teenagers aged 15 to 19 treated at the hospitals because of serious poisonings were examined. Morbidity trends with focus on unintentional poisonings from medicines, alcohol, and drugs were investigated. Regression analysis was applied in the study. In regression, the R Square coefficient of determination was used as a statistical measure. R Square ranges from 0 to 1 . An R Square of 1.0 shows that the regression line perfectly fits the data. The significant level $p$ was considered as statistically considered, when $p \leq 0.05$. The study was approved by institutional Bioethics Committee.

\section{Results and Discussion}

The study revealed that among patients treated in the Klaipeda County (Lithuania) hospitals because of serious poisonings, $48 \%$ were children and young people aged 0 to 19 years. During the study, we focused on poisonings in children aged 0 to 14 years and young people aged 15 to 19 years.

Our study showed that in children aged 0 to 14 years, treated at the hospitals as inpatients, nearly half of children $(48 \%)$ were treated because of the poisonings from medicines. About one third (29\%) of inpatients children were treated because of the poisonings from alcohol. (Figure 1). In children group, only $1 \%$ of serious poisonings were unintentional poisonings from illicit drugs. Nearly one quarter (22\%) of serious poisonings treated in children were unintentional poisonings from other substances (chemicals, etc.) (Figure 1).

The study results revealed that in the young people aged 15 to 19 years, the main substance of serious poisonings was alcohol (52\%). On the second place of hospital-treated

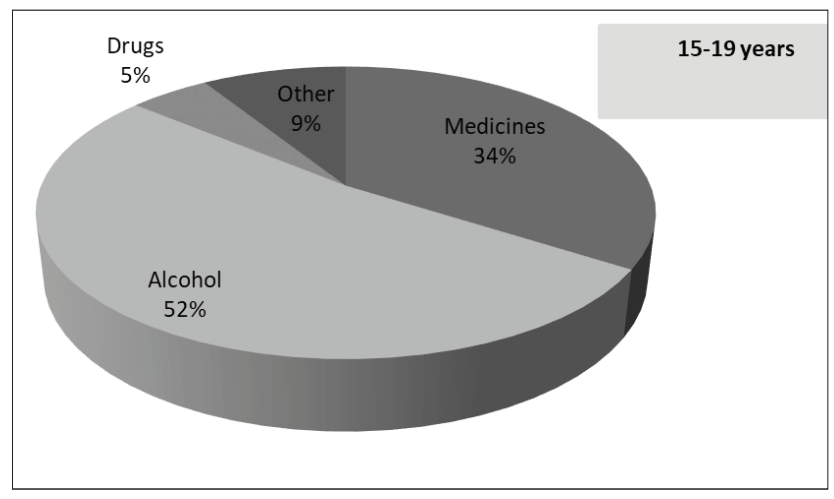

Figure 2. Unintentional poisonings in teenagers aged 15-19 years (inpatients) 
poisonings in teenagers were unintentional poisonings from medicines (34\%). Poisonings due to illegal drugs were very few (5\%). (Figure 2).

The longitudinal study on morbidity trends due to unintentional poisonings showed that in children aged 0 to 14 years group, significant decreasing trend of poisonings from medicines in the whole group was observed $\left(\mathrm{R}^{2}=0.635\right.$; $\mathrm{p}<0.05)$. Similar significant decreasing trend was shown in the poisonings due to alcohol consumption in children aged 0 to 14 years for the whole group $\left(\mathrm{R}^{2}=0.54 ; \mathrm{p}<0.05\right)$. No significant change was observed for the poisonings due to illegal drugs $\left(\mathrm{R}^{2}=0.129 ; \mathrm{p}>0.05\right)$ for children aged 0 to 14 years (for the whole group). However, the numbers of poisonings because of illicit drugs in children group were very few. (Figure 3).

Our study results revealed that in boys aged 0 to 14 years subgroup the significant decrease is observed for the unintentional poisonings due to medicines $\left(\mathrm{R}^{2}=0.639 ; \mathrm{p}<0.05\right)$. The same significant decrease was shown for the poisonings in boys aged 0 to 14 years due to alcohol $\left(\mathrm{R}^{2}=0.554 ; \mathrm{p}<0.05\right)$. No significant changes were shown for the unintentional poisonings because of illicit drugs $\left(\mathrm{R}^{2}=0.0007 ; \mathrm{p}>0.05\right)$ (Figure 4).

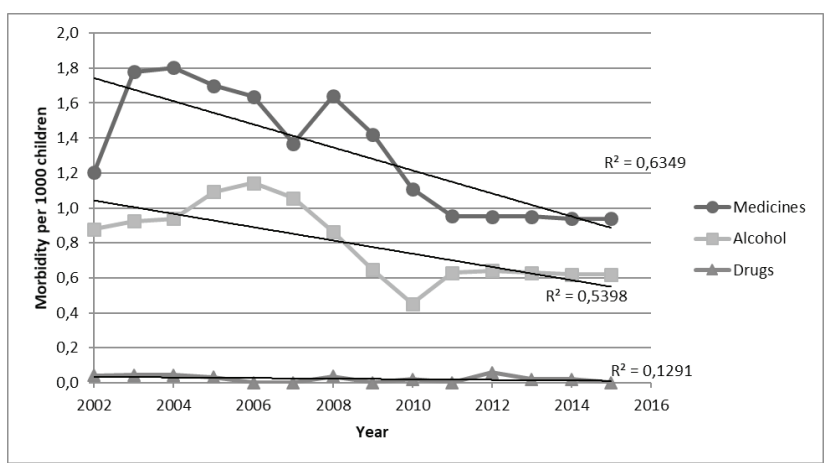

Figure 3. Morbidity trends of poisonings in children aged 0-14 years

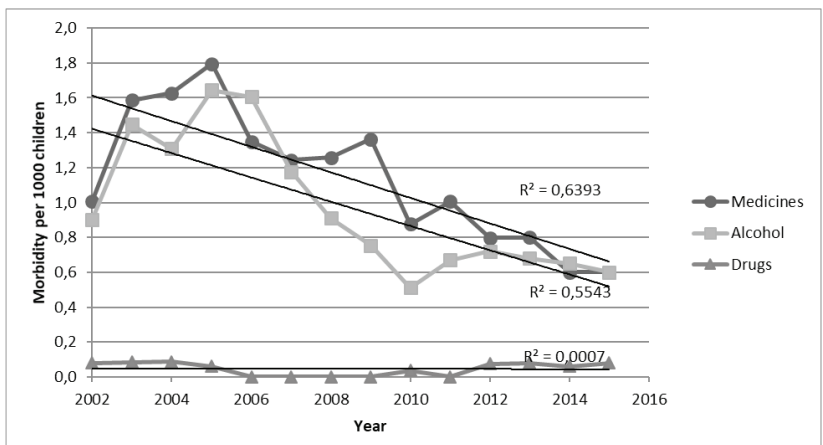

Figure 4. Morbidity trends of poisonings in boys aged 0-14 years
For the girls aged 0 to 14 years subgroup, the longitudinal analysis showed significant decreasing trends of the poisonings from medicines $\left(\mathrm{R}^{2}=0.654 ; \mathrm{p}<0.05\right)$. Whereas no significant change was shown for the poisonings either due to alcohol $\left(\mathrm{R}^{2}=0.027 ; \mathrm{p}>0.05\right)$, nor due to illicit drugs $\left(R^{2}=0.083 ; p>0.05\right)$ (Figure 5).

Our study results revealed that in the young people aged 15 to 19 years, significant decreasing morbidity rate trend of the poisonings from the medicines was observed for the whole group $\left(\mathrm{R}^{2}=0.756 ; \mathrm{p}<0.05\right)$ (Figure 6$)$, and for both boys and girls subgroups. However, morbidity trends of poisonings due to alcohol showed no significant change for the whole teenagers group ( 15 to 19 years) $\left(\mathrm{R}^{2}=0.123 ; \mathrm{p}>0.05\right)$ (Figure 6). The same results were observed for teenagers' boys and girls subgroups; there were no significant changes in the poisonings from alcohol in both subgroups. Morbidity trends of poisonings due to illicit drugs showed no changes in the whole group of teenagers aged 15 to 19 years $\left(\mathrm{R}^{2}=\right.$ $0.142 ; p>0.05$ ) (Figure 6). No significant change was shown for the poisonings due to illicit drugs in the young people aged 15 to 19 years boys and girls subgroups.

Summing up could be stated that the study results revealed declining trends of non-fatal serious poisonings due to

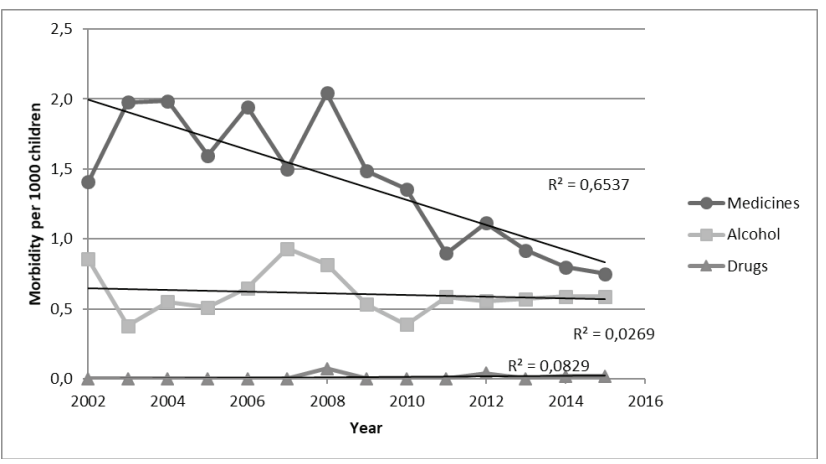

Figure 5. Morbidity trends of poisonings in girls aged 0-14 years

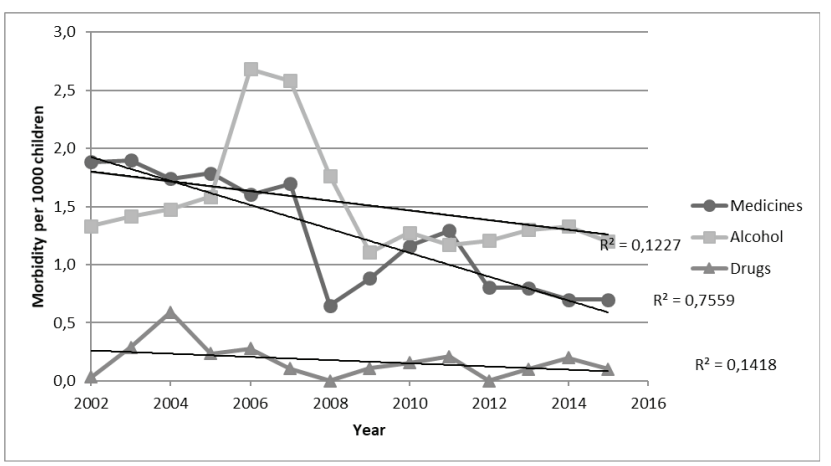

Figure 6. Morbidity trends of poisonings in teenagers aged 15-19 years 
medicines in both children and young people age groups, and male and female subgroups. However, there were no significant changes of poisonings due to alcohol of teenagers aged 15 to 19 years (in the whole group, and boys and girls subgroups), and in girls aged 0 to 14 years. Poisonings due to drugs were very rare, and showed no significant change.

Our study showed that the main substance of poisonings for teenagers was alcohol (52\%). Similar results presented study in Sweden, where teenagers were more often seen as well because of poisoning with alcohol [10]. However, the study performed in New Zealand revealed that for adolescents aged 13 to 18 years the most frequently implicated agents for poisonings were medicines [8]. Our study showed that poisonings in young people (15 to 19 years) from medicines were on the second place (34\%). In the United Arab Emirates poisonings with pharmaceuticals were more common for adolescents and adults In the United States, ingestion of medicines and illicit drugs for the whole population are this biggest problem in society [5]. Our study showed that serious poisonings due to illicit drugs made up only a little part of poisonings both in children group (1\%), and in young people aged 15 to 19 years group (5\%).

For younger children, in our study, the main risks for poisonings were medicines (48\%). Similar results were presented from the countries in different continents (the US, New Zealand, Sweden) where the most frequently implicated agents of unintentional poisonings for younger children were therapeutic agents $[6,8,10$,$] . For children medication dosing$ mistakes, unsupervised ingestions are common ways that children are poisoned [6]. In addition, household chemicals could be possible substances for poisonings in children. Our study revealed lack of younger children supervision by parents and other adults. Easy accessibility to medicines and other substances encourage for awareness rising, information, and safety promotion in community. Parents' education and information (on keeping away medicines from children and teenagers, and storage medicines, toxic products, and alcohol in safe places, where children cannot get them) is of great importance. Child safety prevention projects and programs could be valuable for child poisoning prevention.

Alcohol consumption is another huge problem of poisonings among children and young people. Our study showed that $52 \%$ of young people aged 15 to 19 years, and $29 \%$ of children aged 0 to 14 years were treated in the hospital because of serious poisonings. In addition, no significant change was observed in morbidity due to poisoning trends in girls, aged 0 to 14 years, and in teenagers' group. The underage drinking findings in Europe and in the US show that underage alcohol consumption is one of the leading public health problems $[11,12]$. Underage drinking is still unsolved issue in children. Even more, this problem has a rising tendency. Many young people are experiencing the consequences of drinking too much, at too early an age. Adolescents start drink at younger ages. Prevention of alcohol consumption among children is needed with focus on legislation and enforcement. Alcohol consumption prevention measures should be implemented at national and local levels. Issues of reducing accessibility to alcohol for children should be underlined. Comprehensive injury prevention and safety promotion measures for children and young people could reduce numbers of fatal and non-fatal deaths, and help children to live their lives at highest quality level.

\section{Conclusions}

The main substance of unintentional poisoning in children aged 0 to 14 years were medicines (on the second place - alcohol), whereas for young people aged 15 to 19 years was alcohol. The study results revealed declining trends of non-fatal poisonings due to medicines in both children and teenagers groups, and male and female subgroups. However, there were no significant changes of poisonings due to alcohol in young people aged 15 to 19 years, and in girls aged 0 to 14 years. Poisonings due to drugs were very rare, and showed no significant change. Parents and children education and information within child safety prevention projects/programs could influence the decrease in poisonings due to medicines. However, more attention should be put on prevention of alcohol use among children and teenagers, with focus on legislation and enforcement.

\section{References}

1. Holder Y, Matzopoulos R, Smith N. Poisons. In: Peden M., Oyegbite K., Ozanne-Smith J., Hyder A.A., Branche C, Rahman F., Rivara F., Bartolomeos K. (eds). World report on child injury prevention. Geneva: World Health Organization (WHO), 2008.

2. Aldridge E, Sethi D, Yon Y. Injuries: a call for public health action in Europe, WHO Regional Office for Europe, Copenhagen, 2017.

3. European Association of Injury Prevention and Safety Promotion (EuroSafe). Working together to reduce the burden of home and leisure accidents in Europe. Available at: http://www. eurosafe.eu.com/home, accessed 30 October 2017.

4. Kisser R, Walters A, Rogmans W, Turner S, Lyons RA. Injuries in the European Union. European Association of Injury Prevention and Safety Promotion (EuroSafe), 2017.

5. US National Center for Health Statistics, NCHS Fact Sheet, August, 2017. Available at: https://www.cdc.gov/nchs/data/ factsheets/factsheet_drug_poisoning.pdf, accessed 20 September 2017.

6. Centers for Disease Control and Prevention (CDC), US, Poiso- 
ning Prevention. Available at: https://www.cdc.gov/safechild/ poisoning/index.html, accessed 25 September 2017.

7. Even K.M., Armsby C.C., Bateman S.T. Poisonings requiring admission to the pediatric intensive care unit: A 5-year review. Clinical Toxicology 2014; 52(5) 2014. https://doi.org/10.3109/15563650.2014.909601

8. Fan AY, Che AH, Pan B, Yang C, Coulter CV, Shieffelbien L. et al. Investigating childhood and adolescence poisoning exposures in New Zealand reported to the National Poisons Centre during 2000-2009. Asia Pacific Journal of Medical Toxicology 2013; 2(2): 52-57.

9. Hameed FA, Ansri HK, Al-Najjar FJ. Prevalent poisonings in adolescents and adults in Dubai: A compendium from Rashid Hospital. Asia Pacific Journal of Medical Toxicology 2014; 3(3): 115-119.

10. Hedstrom EM, Bergstrom U, Michno P. Injuries in children and adolescents - analysis of 41, 330 injury related visits to an emergency department in northern Sweden. Injury 2012; 43(9): 1403-1408.

https://doi.org/10.1016/j.injury.2011.01.027

11. National Institute on Alcohol Abuse and Alcoholism (US). Underage Drinking. Available at: https://pubs.niaaa.nih.gov/ publications/UnderageDrinking/Underage_Fact.pdf, accessed 28 August 2017.

12. Inchley J, Currie D, Young T, Samdal O, Torsheim T, Augustson L. et al. (eds). Growing up unequal: gender and socioeconomic differences in young people's health and well-being. Health Behaviour in School-Aged Children (HBSC) Study: International Report from the 2013/2014 Survey. Copenhagen: WHO regional Office for Europe, 2016.

13. Gaidelyte R, Madeikyte N.(eds). Injuries and poisonings in Lithuania, 2015. Vilnius: Health Information Center of Hygiene Institute, 2015.

VAIKŲ IR PAAUGLIŲ NETYČINIŲ APSINUODIJIMŲ SERGAMUMO TENDENCIJOS KLAIPE்DOS APSKRITYJE (LIETUVA)

\section{B. Strukčinskienė, S. Griškonis}

Raktažodžiai: apsinuodijimai, vaikai, paaugliai, tendencijos, sergamumas.

Santrauka

Vaikų, paauglių ir jaunų žmonių netyčiniai apsinuodijimai su- daro didelę mirtingumo ir sergamumo dali visame pasaulyje. Tyrimo tikslas buvo ịvertinti vaikų ir paauglių sergamumo tendencijas dèl netyčinių apsinuodijimų, daugiausia dėmesio skiriant netyčiniams apsinuodijimams dèl vaistų, alkoholio ir nelegalių narkotikų Klaipėdos apskrityje (Lietuvoje).

Tyrimui duomenys (2003-2015 m.) buvo gauti iš Sveikatos draudimo fondo ir Klaipėdos statistikos departamento. Buvo atliktas longitudinis tyrimas, taikyta regresinè analizè. Buvo ištirti 0-14 metų vaikai ir 15-19 metų paaugliai, gydyti ligoninèje dèl sunkių apsinuodijimų. Apskaičiuotas sergamumas 1000 vaikų.

Tarp visų pacientų, gydytų Klaipėdos apskrities ligoninėse dẻl rimtų apsinuodijimų, 48\% sudare 0-19 metų amžiaus vaikai ir paaugliai. 0-14 metų amžiaus vaikų, kurie buvo gydomi ligoninėse dèl sunkių netyčinių apsinuodijimų, grupejje 48 proc. apsinuodijimų sudarè apsinuodijimai medikamentais, 29 proc. - apsinuodijimai alkoholiu, 1 proc. - nelegaliais narkotikais ir 22 proc. - kitomis medžiagomis. 15 - 19 metų amžiaus paauglių grupejje pagrindinè sunkių netyčinių apsinuodijimų priežastis buvo apsinuodijimai alkoholiu (52\%), antroje vietoje buvo apsinuodijimai medikamentais (34\%), o apsinuodijimai nelegaliais narkotikais sudare tik 5 procentus visų apsinuodijimų. Tyrimas parodè, kad pagrindinė apsinuodijimo medžiaga 0-14 metų amžiaus vaikų grupejje buvo medikamentai, o 15-19 metų amžiaus paauglių grupejje buvo alkoholis. Tyrimas atskleide, kad 0-14 metų amžiaus vaikų ir 15-19 metų amžiaus paauglių apsinuodijimai medikamentais tiriamuoju laikotarpiu mažejo tiek visoje grupeje, tiek berniukų ir mergaičių pogrupiuose. Tačiau 15-19 metų amžiaus paauglių grupejje ir 0-14 metų amžiaus mergaičių pogrupyje tiriamuoju laikotarpiu apsinuodijimų alkoholiu kategorijoje reikšmingų pokyčių nenustatyta. Tirtose vaikų ir paauglių grupėse sunkių apsinuodijimų nelegaliais narkotikais buvo nedaug, ir tiriamuoju laikotarpiu jokių reikšmingų pokyčių nustatyta nebuvo. Tẻvų ir vaikų švietimas ir informavimas vykdant vaikų saugos prevencijos projektus bei programas igalintų sumažinti vaikų apsinuodijimus medikamentais. Daugiau priemonių turètų būti skiriama vaikų ir paauglių alkoholio vartojimo prevencijai, daugiausia demesio skiriant teisinėms priemonėms ir įstatymų vykdymo kontrolei.

Adresas susirašinèti: birutedoctor@hotmail.com

Gauta 2017-11-06 